\title{
Hypoxia-induced soluble CD137 in malignant cells blocks CD137L-costimulation as an immune escape mechanism
}

\author{
Sara Labiano ${ }^{1 *}$, Asis Palazon', Elixabet Bolaños-Mateo ${ }^{1}$, Arantza Azpilicueta', Alfonso Rodriguez', \\ Aizea Morales-Kastresana', Elena Marin ${ }^{1}$, Alfonso Gurpide², Maria Rodriguez-Ruiz ${ }^{1}$, M Angela Aznar', \\ Maria Jure-Kunkel' ${ }^{3}$ Ignacio Melero ${ }^{1}$
}

From Society for Immunotherapy of Cancer 29th Annual Meeting

National Harbor, MD, USA. 6-9 November 2014

Hypoxia is a common feature in solid tumors that has been implicated in immune-evasion. Previous studies from our group have shown that hypoxia up-regulates the co-stimulatory receptor CD137 on activated T lymphocytes and on vascular endothelial cells. In this study, we show that exposure of mouse and human tumor cell lines to hypoxic conditions $\left(1 \% \mathrm{O}_{2}\right)$ promotes $\mathrm{CD} 137$ transcription. However, the resulting mRNA is predominantly an alternatively spliced form that encodes for a soluble variant, lacking the transmembrane domain. Accordingly, soluble CD137 (sCD137) is detectable by ELISA in the supernatant of hypoxia-exposed cell lines and in the serum of tumor-bearing mice. sCD137, as secreted by tumor cells, is able to bind to CD137-Ligand (CD137L). Our studies on primed T lymphocytes in coculture with stable transfectants for CD137L demonstrate that tumor-secreted sCD137 prevents co-stimulation of T lymphocytes. Such an effect results from preventing the interaction of CD137L with the transmembrane forms of CD137 expressed on T lymphocytes undergoing activation. This mechanism is interpreted as a molecular strategy deployed by tumors to repress lymphocyte co-stimulation via CD137/CD137L.

\section{Authors' details}

${ }^{1}$ Immunology and Immunotherapy, Center for Applied Medical Research, Pamplona, Spain. ${ }^{2}$ Oncology, CUN, Pamplona, Spain. ${ }^{3}$ Oncology Drug Discovery division, Bristol-Myers Squibb Pharmaceutical Research Institute, Princeton, NJ, USA.

'Immunology and Immunotherapy, Center for Applied Medical Research, Pamplona, Spain

Full list of author information is available at the end of the article
Published: 6 November 2014

doi:10.1186/2051-1426-2-S3-P218

Cite this article as: Labiano et al:: Hypoxia-induced soluble CD137 in malignant cells blocks CD137L-costimulation as an immune escape mechanism. Journal for ImmunoTherapy of Cancer 2014 2(Suppl 3):P218.
Submit your next manuscript to BioMed Central and take full advantage of:

- Convenient online submission

- Thorough peer review

- No space constraints or color figure charges

- Immediate publication on acceptance

- Inclusion in PubMed, CAS, Scopus and Google Scholar

- Research which is freely available for redistribution

Submit your manuscript at www.biomedcentral.com/submit
() Biomed Central 